\title{
"GREAT RUSSIAN WORD": The Third International Livadia Forum, Yalta, 5-6 June 2017
}

\section{«ВЕЛИКОЕ РУССКОЕ СЛОВО»: Третий международный Ливадийский форум, Ялта, 5-6 июня 2017}

The $11^{\text {th }}$ International Festival of Russian and Slavic Culture "The Great Russian Word" was held from $2-12^{\text {th }}$ June in the city of Yalta with a plethora of festivities, ranging from celebrations of the birthday of the great Russian poet Alexander Pushkin to other cultural and academic - scientific programmes. As part of this international festival, the $3^{\text {rd }}$ International Livadia Forum was held on June 5-6, 2017 in the city of Yalta, one of the most beautiful leisure centres on the peninsula, with its picturesque landscape and breathtaking view of the sea. It also has immense historical significance, for it was here, in the Livadia palace that Joseph Stalin, Winston Churchill and Franklin Roosevelt conferred to shape a post-war peace that represented not just a collective security order but a plan to give self-determination to the liberated peoples of postNazi Europe.

The title of the Festival of Russian and Slavic Culture corresponds to the words of the Great Russian poetess Anna Akhmatova, who during the war (in 1942) wrote:

Не страшно под пулями мертвыми лечь,

Не горько остаться без крова,

И мы сохраним тебя, Русская речь,

Великое русское слово.

Свободным и чистым тебя пронесем,

И внукам дадим, и от плена спасем

Навеки.

Let bullets kill us-we are not afraid,

nor are we bitter, though our housetops fall.

We will preserve you, Russian speech,

from servitude in foreign chains,

keep you alive, great Russian word,

fit for the songs of our children's children,

pure on their tongues, and free.

(From "Poems of Akhmatova", selected, translated and introduced by Stanley Kunitz with Max Hayward)

The words of the poetess Anna Akhmatova define the main aim of the Forum to promote the Russian language, literature and culture and its increasing role in the 
development of integration processes in the post-Soviet space, as well as a common cultural and humanitarian space.

The forum was divided into three sections, namely, "The concept of the Russian world: turning points in history"; "Russian language: educational and legal aspects"; "Literature is a cultural symbol of Russia". "Crimean Muse" which were conducted in the historical places of Yalta - Alupka Palace, Vorontsov Palace and the House-Museum of Anton Chekhov.

Each section was represented by invited experts and scholars from Russia and all over the world - China, USA, Ukraine, Kazakhstan, Estonia, Afghanistan, Australia, Switzerland, Vietnam and India to name a few.

The session on Russian language: educational and legal aspects was chaired by Prof. Ludmila Verbitskaya, President of St. Petersburg State University and President of the Russian Academy of Education. In her opening remarks Prof Verbitskaya stressed upon the increasing role of Russian language in the world and the importance of preserving its beauty and richness. Other participants from different countries talked specifically about their personal experiences in teaching Russian language in their countries as well as the difficulties they faced in terms of acquiring appropriate text books and other teaching aids. Special emphasis was laid on the teaching of Russian language to the second generation compatriots living abroad in a bilingual atmosphere. The delegates also deliberated on the scope of the language at primary as well as higher education levels.

The session on "Literature is a cultural symbol of Russia". "Crimean Muse" could not have been held in a more appropriate place - the house museum of Anton Chekhov. This session was chaired by the Vice chancellor of Lomonosov Moscow State University V.A. Sadovnichi and attended by enthusiastic Russian literature lovers from all over the world. Many participants specifically highlighted the theme of Crimea in the works of many Russian writers. Others talked about the depth and significance of Russian literature in shaping basic humanistic values. In tune with the aim of the Forum one participant emphasized on the importance of inculcating a 'poetic' attitude towards life in these troubled times. Some foreign delegates suggested the need for active exchange between modern writers of Russia and their respective countries.

In the evening the delegates were invited to a grand variety entertainment program which was attended by many important dignitaries from the Crimea, other parts of Russia, including the Chairman of the Federation Council, Valentina Matvienko.

She red out a message from the president, which amongst other things said "The Russian language is the main unifying cement for Russia's multi-ethnic people and a solid link with our compatriots abroad. The efforts of those taking part in the forum therefore deserve our greatest respect, as does the work of all who devote their talent and energy to the noble and important task of promoting the Russian language and our culture's rich values.

I am sure that this forum will be full of interesting and substantive discussions and will take place in an atmosphere of creativity and development. Of course, I am sure it will also offer all taking part the chance to see Crimea's historical monuments and unique nature". 
An exhilarating concert by the Turetskii choir left the audience in a swinging mood and it kept asking for more. The evening came to end after a sumptuous banquet.

The 3rd International Livadia Forum was a grand success and paved the way for further development and more cooperation between the concerned bodies for promotion of Russian language, literature and culture in the world. It concluded with the hope of meeting again in the coming year.

(C) Meeta Narain, 2017

\section{For citation:}

Meeta Narain (2017) "Great Russian Word": The third International Livadia Forum, Yalta, 5-6 June 2017. Russian Journal of Linguistics, 21 (3), 656-658. doi 10.22363/2312-91822017-21-3-656-658.

\section{Bio Note:}

Meeta Narain, Professor \& Chairperson, Center of Russian Studies, SLL\&CS, Jawaharlal Nehru University. Research interests: Bilingualism, Multilingualism, Sociolinguistics, Russian language studies, language and culture. Contact information: e-mail: meetanarain@hotmail.com.

\section{Для цитирования:}

Meeta Narain. "Great Russian Word": The Third International Livadia Forum, Yalta, 5-6 Јune // Вестник Российского университета дружбы народов. Серия: Лингвистика. 2017. T. 21. № 3. C. 656-658. doi 10.22363/2312-9182-2017-21-3-656-658.

\section{Сведения об авторе:}

Мита Нарайн, профессор, руководитель Центра русских исследований (SLL\&CS), Университет им. Джавахарлала Неру. Сфера научных интересов: билингвизм, мультилингвизм, социолингвистика, русский язык, язык и культура. Контактная информация: e-mail: meetanarain@hotmail.com. 